Jadila: Journal of Development and Innovation

E-ISSN: 2723-6900

in Language and Literature Education

P-ISSN: 2745-9578

Publisher: Yayasan Karinosseff Muda Indonesia

Volume 1 Number 4, 2021

Page: $451-469$

\title{
An Analysis on Forms and Functions of Code-Switching and Code-Mixing Used in Drama Performance
}

\author{
Shafira Annisa Masruroh \\ IAIN Salatiga \\ shafiraannisamasruroh@gmail.com \\ Setia Rini \\ IAIN Salatiga \\ setiarini.setia@gmail.com
}

\begin{abstract}
The study was conducted in order to describe the forms and the functions of codeswitching and code-mixing in drama performance of ALE of the students of ICP batch 2017. The study was descriptive qualitative research. The data are collected by observation and documentation in the drama performance in Art and Language Exhibition 'Prahara Ing Argabelah'. The finding shows that 24 unit analysis of codeswitching found 6 used tag-switching, 15 used inter-sentential switching, and 3 used intra-sentential switching. Furthermore, 27 unit analysis of code-mixing performed 21 intra-sentential code mixing, 5 intra-lexical code mixing, and 1 involving a change of pronunciation. Then, from 24 unit analysis of code-switching, the researcher found six functions in the drama conversation. There are 6 addressee specifications, 2 repetitions, 7 interjections, 1 message qualification, 2 personalization and objectivizations, and 6 facilities of expression. Moreover, the researcher just found 3 functions from 27 unit analysis of code-mixing. There are 1 repetition, 2 message qualifications, and 24 facilities of expression.
\end{abstract}

Keywords: Code-Switching; Code-Mixing; Drama

\section{A. Introduction}

In order to be understood by other people, human beings as social creatures need language to communicate and convey their minds, ideas, and emotions. In addition, in the social world, human beings need to be supported and helped to create a pleasant situation. According to this phenomenon, communication between people often requires language. In daily life, negotiation, planning, studying, and even playing a drama, communication might be in conversation. People also can change their language from one language when communicating. This is known as codeswitching and code-mixing. 
Jadila: Journal of Development and Innovation

E-ISSN: 2723-6900

in Language and Literature Education

P-ISSN: 2745-9578

Publisher: Yayasan Karinosseff Muda Indonesia

Volume 1 Number 4, 2021

Page: $451-469$

Sumarsih (2014:78) stated that even in a paragraph, code switching is the use of multiple languages in words, phrases, and sentences. In bilingual and multilingual cultures, code switching happens when a person changes their language, variety, or dialect to another language. In any form of situation and area, like everyday conversation, negotiation, research, even playing a drama, people can do code switching. On the other hand, in Sumarsih (2014:79), Jendra (1988) describes code mixing as symptom of language use in which "a mixture or combination within the same clause of different variations". Code mixing is performed only by inserting a single word and clause when the speaker merely mixes the terms in the sentence or clause to make them more interesting without changing the subject.

Based on the researcher's experience in International Class Program, students of the International Class Program are the selected students who have a good basic in English, memorizes some part of the holy Quran, and good knowledge about Indonesian culture. Those selected students are to be prepared for continuing to study overseas or having an international job in the future. For those reasons, IAIN Salatiga has several programs for International Class Program students to enhance their ability in English. The students suggested using English as their communication language in daily life. In the seventh semester, the students have to do the teaching practice abroad such as in Malaysia and Thailand to enrich their teaching skills and experience. International Class Program also has a big agenda namely ALE (Art and Language Exhibition). In this agenda, the students have to perform a drama about Javanese classical drama using English and Arabic. ALE classified as drama performance. Drama performance can be simply defined as actions that are performed for audiences. When the researcher accompanied the students of the International Class Program in preparing for ALE, the researcher found some utterances produced by the students contains switching and mixing the language. 
Jadila: Journal of Development and Innovation

E-ISSN: 2723-6900

in Language and Literature Education

P-ISSN: 2745-9578

Publisher: Yayasan Karinosseff Muda Indonesia

Volume 1 Number 4, 2021

Page: $451-469$

The study focuses on the forms and functions of code-switching and codemixing used in drama performance of ALE performed by the students of International Class Program batch 2017.

The purpose of this research are to describe the forms and to examine the functions of code-switching and code-mixing used in drama performance of ALE performed by the students of International Class Program batch 2017.

\section{Code-Switching}

Language is a tool for human communication. Language also become a code in communication among people. In interacting with two or more individuals, code may be used to replace the method. People are usually required to select a specific code whenever they choose to speak, according to Wardhaugh (2006:101), and they may also decide to switch from one code to another or to mix codes even within very short utterances at times, thus creating a new code in a process known as codeswitching.

Code switching is the one of alternative way to bilingual or multilingual of two or more languages in the same conversation. According to Risdianto (2013:45), code switching is switching between two or more languages or language varieties of the context of a single conversation. Another definition, Herk (2012) in Nurliana (2017:42) states that a common occurrence in bilingual and multilingual communities, code switching refers to instance in which people alternate between at least two languages or language varieties of a single conversation (across sentence or clause boundaries).

It can be concluded that code switching is the alternate way to use two or more languages within the sentence or utterance. Code switching is a change that appear in the same sentence by a speaker or writer from one language to another. 
Jadila: Journal of Development and Innovation

E-ISSN: 2723-6900

in Language and Literature Education

P-ISSN: 2745-9578

Publisher: Yayasan Karinosseff Muda Indonesia

Volume 1 Number 4, 2021

Page: $451-469$

Poplack (1980) as quoted by Heeti and Addely (2016), proposed a wellknown framework that identifies three different types of switching which are tagswitching, inter-sentential, and intra-sentential.

\section{Tag-switching}

According to Holmes (2013:35) tag switching, sometimes called emblematic switching, is simply an interjection or a linguistic tag in other languages. Moreover, Al Heeti and Al Addely (2016:11) stated that tag-switching involves inserting a tag or short phrase in one language into an utterance that is otherwise entirely in another language.

Example:

A : Ralin itu sama cantiknya dengan Pevita, right?

(Ralin is as gorgeous as Pevita, right?)

B : No, Pevita lebih cantik daripada dia.

(No. Pevita is more gorgeous than her.)

From the conversation, it shows that the speakers use tag switching in their utterance such as "right" and "no". They do tag switching in the end of their utterance and in the beginning of their utterance.

\section{Inter-sentential switching}

Holmes (2013:45) stated that inter-sentential is switching at sentence boundaries or usually only short fixed phrases in one language on the end of sentences in the other language. Al Heeti and Al Addely (2016:11) added intersentential switching involves switching at sentential boundaries where one clause or sentence is in one language and the next clause or sentence is in the other.

Example:

"Tiba-tiba listrik di rumahku mati. I don't know what happen." 
Jadila: Journal of Development and Innovation

E-ISSN: 2723-6900

in Language and Literature Education

P-ISSN: 2745-9578

Publisher: Yayasan Karinosseff Muda Indonesia

Volume 1 Number 4, 2021

Page: $451-469$

(The electric in my house suddenly off. I don't know what happen.)

We can see from the example above, in the end of the statement the speaker switch his language into English. So, it can be mentioned that the type of code switching that appears on the example above is Inter-sentential code switching.

\section{Intra-sentential switching}

Intra-sentential switches only occur within the sentence, so you may only switch between an adjective and a noun if both language use the same order for that adjective and noun (Holmes, 2013:44-45). In addition, Wardhaugh (2006:108) said that intra-sentential switching can also be a switch of codes within a simple utterance without any associated topic change.

Example:

A : Pergi vacation sama teman-teman mau nggak?

(Do you want to go vacation with our friends?)

B : Kemana emangnya? Aku recommend ke Labuan Bajo.

(Where are we going? I recommend Labuan Bajo.)

The example of the conversation above shows that the speakers switch their language in the middle of their utterance. The speakers speak in Indonesian language and they insert a word in English. "Vacation" and "recommend" are the words they insert in English. Therefore, the English words that come from their speech in forms of code switching called as Intra-sentential code switching.

\section{Code-Mixing}

Code-mixing may occur within a single sentence or utterance in multilingual or bilingual setting where speakers share more than one language (syafryadin \& Haryani, 2020; Syafryadin, Febriani, Rahmawati, 2020). It has similarity with code 
Jadila: Journal of Development and Innovation

E-ISSN: 2723-6900

in Language and Literature Education

P-ISSN: 2745-9578

Publisher: Yayasan Karinosseff Muda Indonesia

Volume 1 Number 4, 2021

Page: $451-469$

switching because it is also using more than one language in one sentence. Ansar (2017:35) was quoting Kachru in Nusjam (2004), code mixing is the term refers to the use of one language into other, and by such a language mixture developing a new restricted or not so restricted code of linguistic interaction.

Code mixing can occur because the speaker of the language does not find the suitable terms that can be used. Saputro (2013:3) as cited by Wulandari (2016:72) defines code mixing as the use of more than one language that speakers or writers mix two codes or more language on discourse; the main characteristics in code mixing are relaxed situations and informal situation. Another definition provided by Risdianto (2013:41), code mixing refers to the mixing of two or more languages or language varieties of speech.

From the definition above, it can be concluded that code mixing is the use of two or more languages or mix from one code to another within a sentence or utterance without any change at all situation. Code mixing usage depends on what language that the speaker master, it may occur because the speaker does not find suitable terms that can be used.

According to Hoffman (1991), there are three types of code mixing based on syntactical patterns. Those are intra-sentential code mixing, intra-lexical code mixing, and involving a change of pronunciation.

\section{Intra-sentential code mixing}

The meaning of intra-sentential code mixing is the appearance of a phrase, clause, or a sentence boundary in a conversation both oral and written. The mixing code is in sentence boundary.

Example:

A : Besok saya ada work interview di perusahaan.

(Tomorrow I will face work interview in the company.) 
Jadila: Journal of Development and Innovation

E-ISSN: 2723-6900

in Language and Literature Education

P-ISSN: 2745-9578

Publisher: Yayasan Karinosseff Muda Indonesia

Volume 1 Number 4, 2021

Page: $451-469$

B : Ehmm. Ya kamu harus well prepared supaya diterima.

(Ehmm. You should well prepared so that the company will accept you.)

The speakers combine the language between Indonesian and English from the example of the conversation between $\mathrm{A}$ and $\mathrm{B}$. Therefore, intra-sentential code mixing is called the mixing they do in their conversation since they mix the languages in a sentence boundary.

\section{Intra-lexical code mixing}

Intra-lexical code mixing appears in the conversation when the speakers attach a word boundary in their utterance.

Example:

A : Kamu tidak pernah nge-view status Whatsapp saya!

(You never saw my Whatsapp story!)

B : Hehe. Saya belum nge-save nomer Whatsapp kamu.

(Hehe. I haven't saved your Whatsapp number yet.)

Based on the example above, it can be said the conversation between first speaker and second speaker do type of code mixing in Intra-lexical code mixing because both speaker gives the addition of word "view" and "save" with "nge". So, it can be conclude that both speakers mix the language between English and Indonesian language at the level of word and it is called with Intra-lexical code mixing.

\section{Involving a change of pronunciation}

At the phonological level, this type of code mixing occurs. This means that the word they say is altered to the Indonesian phonological structure when Indonesian people speak in English. For example, the phenomenon of this form of code mixing 
Jadila: Journal of Development and Innovation

E-ISSN: 2723-6900

in Language and Literature Education

P-ISSN: 2745-9578

Publisher: Yayasan Karinosseff Muda Indonesia

Volume 1 Number 4, 2021

Page: $451-469$

happens to the actress from Indonesia, Cinta Laura. She also seems to speak English while Cinta Laura talks in Indonesian, because when she speaks in Indonesian, her pronunciation is a bit the same as when she speaks English. Another example is that Indonesian people claim that the word "strawberry" is "stroberi".

\section{Functions of Code-Switching and Code-Mixing}

Marasigan (1983) as quoted by Adipratama (2014) proposed several functions of code switching and code mixing, there are quotation, addressee specification, repetition, interjection, message qualification, personalization and objectivization, and facility expression.

\section{Quotation}

According to Marasigan (1983), quotation occurs when the subject directly or implicitly references themselves or others to sound more believeable to the addressees. In fact, a quotation serves as confirmation that what the speaker was saying was a fact and the addressees had to believe them.

Example: Pas aku ulang rekaman itu, dia itu emang bilang really need to go holiday and chill gitu.

In order to preserve the message, the example above indicates that the speaker quoted others in English.

\section{Addressee Specification}

This type perceives not only the interacting members of the speech event but also perceives that their language behavior may be more than merely a matter of individual preference or facility, but also a problem of role relations. Furthermore, the addressee specification occurs immediately to convey the message to the listener even though the message is posted. 
Jadila: Journal of Development and Innovation

E-ISSN: 2723-6900

in Language and Literature Education

P-ISSN: 2745-9578

Publisher: Yayasan Karinosseff Muda Indonesia

Volume 1 Number 4, 2021

Page: $451-469$

Example: Penonton itu lebih tertarik for listen to their song or watch their music video.

\section{Repetition}

Repetition may serve to clarify what is said, amplify, or emphasize a message, or mark a joke by repeated the language in the other code. Besides, repetition aimed to make the message clearer and able to be understood by the listener.

Example: Kegiatan ini sangat menyenangkan, it's fun!

\section{Interjection}

According to Marasigan (1983), this function usually to express strong emotions or feelings. Interjection appears as the substitution of the interaction form the "we" to "they" code or from the "they" to the "we" code. It can be inferred that the speaker used interjection to switch and mix the code.

Example: Tidur, it's your time to sleep!

\section{Message Qualification}

The time definition is also represented by this function. In addition, this role was often intended at a specific time to highlight something. Moreover, message qualification occurs when a subject starts in one language and is preceded in another language by reinforcement or qualification. So, a reasonable clarification to be understood is given by the message.

Example: The power of highlighter jadi bikin muka kelihatan sehat dan bersinar.

\section{Personalization and Objectivization}

This function to express someone's personal opinion whether it refers to specific instance or fact. Furthermore, Marasigan (1983) personalization and 
Jadila: Journal of Development and Innovation

E-ISSN: 2723-6900

in Language and Literature Education

P-ISSN: 2745-9578

Publisher: Yayasan Karinosseff Muda Indonesia

Volume 1 Number 4, 2021

Page: $451-469$

objectivization function into: "objective marks that the speaker gives about the reality" and "the speaker's subjective statement as personalizing marks".

Example: Selamat ulang tahun, wish you all the best.

\section{Facility Expression}

Facility expression occurs when the speaker has a difficulty in finding the proper word to use at the time he/she speaking or merely as a sign of the subject's lack of familiarity with the style he/she is using.

Example: Yang terpenting adalah mengejar deadline yang udah dibuat.

\section{Drama Performance}

As cited by Admaja (2013), Reaske (1966) clarified that drama is a literary work that illustrates life and human activity through the interpretation of different acts. According to Chomsky as cited by Barman (2012:115), performance is the transformation of competence into everyday speech. Art and Language Exhibition is an annual event held by the International Class Program of IAIN Salatiga. Student from International Class Program are the selected students who have good basic in English and Arabic. In their daily life, they use English, Arabic, Indonesian even Javanese to communicate with other student in dormitory. This habit flows in a drama performance. ALE can be interpreted as a language performance.

They perform a traditional dance and Javanese classical drama. The drama used English, Arabic, Javanese, and Indonesian as the character's language in their conversation. This event became one of the flagship activities from ICP. ALE is a place for ICP students to show and to explore their ability in language and Indonesian culture.

ALE entitled "Prahara Ing Argabelah" was performed by the students of ICP batch 2017 in April 23, 2019. "Prahara Ing Argabelah" is about love and sacrifice. 
Jadila: Journal of Development and Innovation

E-ISSN: 2723-6900

in Language and Literature Education

P-ISSN: 2745-9578

Publisher: Yayasan Karinosseff Muda Indonesia

Volume 1 Number 4, 2021

Page: $451-469$

The main character is Bagaspati, a giant with bad appearance and bad smell. He lived his life alone. He really wanted to have a child, so he went into meditation. God gave him a beautiful daughter, called Pujawati, after long meditation. Pujawati is rising wonderfully. She had a dream one day about a handsome man. Then she told her father that she should find that guy. Bagaspati went to find the man and bring the man to Argabelah. Narasoma, a handsome man from Mandraka, is the man that Pujawati dreamt of. From the first sight, Narasoma fell in love with Pujawati, and then Bagaspati asked him to marry Pujawati, promising him that he would never leave her alone. Narasoma betrayed his promise and engaged Bagaspati in a duel because, as his father-in-law, he did not like Bagaspati. Bagaspati cannot die because he has Chandrabirawa, a superpower. He gave Narasoma his power and told him that he would love and never leave Pujawati alone.

Students of ICP are the selected students from the Islamic Education Department, Arabic Department, and English Education Department who have a good basic in English and Arabic. The students of ICP batch 2017 consist of 17 women and a man.

\section{B. Research Methodology}

The research was descriptive qualitative research. According to Moloeng (2009) in Maghfiroh (2018), a descriptive qualitative is a study of which the data are in written and oral word forms. The data are analyzed descriptively based on the drama conversation in ALE. The data were collected by having observation and documentation. The data in this study is from the utterances which are contained code-switching and code-mixing on the drama performance in ALE entitled "Prahara Ing Argabelah" which performed by ICP students batch 2017. In this research, the main instrument is the researcher herself, and also the researcher needs supporting instruments such as a book, pen, digital dictionary, and laptop. In this research, the 
Jadila: Journal of Development and Innovation

E-ISSN: 2723-6900

in Language and Literature Education

P-ISSN: 2745-9578

Publisher: Yayasan Karinosseff Muda Indonesia

Volume 1 Number 4, 2021

Page: $451-469$

researcher analyzed the forms and functions of code-switching and code-mixing used in drama performance. In order to verify the validity of the data, the researcher chose triangulation. Denzin (1978) proposed four types of triangulation, there are the use of multiple methods, multiple sources of data, multiple investigators, and multiple theories to confirm emerging findings.

\section{Result and Discussion \\ Forms of Code-Switching}

To analyze the data of code-switching, the researcher used theory by Poplack. From three types of code-switching, the researcher found all types of code-switching in the drama conversation of ALE "Prahara Ing Argabelah". They are tag-switching, inter-sentential switching, and intra-sentential switching. The finding of the research about code-switching in the drama conversation of ALE "Prahara Ing Argabelah" as follows:

\section{Tag-Switching}

Tuman= I suggest to Ndoro Ayu soon talk to Resi Bagaspati!

Pujawati= Is that so?

Tuman $=Y a$, it works, trust me Ndoro Ayu.

The italic word classified as tag-switching. Tuman switches the code in her utterance in other language. She used interjection at the beginning of her utterance to expose her strong intention to answer the question.

Pujawati= Ealah Kangmas, Kangmas. Why this happens to you? 
Jadila: Journal of Development and Innovation

E-ISSN: 2723-6900

in Language and Literature Education

P-ISSN: 2745-9578

Publisher: Yayasan Karinosseff Muda Indonesia

Volume 1 Number 4, 2021

Page: $451-469$

"Ealah" was expression that the speaker used in switching her utterance. She used Javanese while the whole language used English. So that the researcher assumes that the italic word classified as tag-switching.

\section{Inter-Sentential Switching}

Tuman= Ndoro Ayu, are you sleepy? Simbok nembang ya?

The utterance above shows a switch in a sentence boundary. In this part of drama conversation, English is the main language that used by the characters. Tuman said an English utterance "Ndoro Ayu, are you sleepy?", which followed by Indonesian sentence "Simbok nembang ya". Therefore, this data categorized as intersentential switching because the speaker switch the language between sentences.

Narasoma= مَنْ آنْتِ؟

Sopo iki?

This data included inter-sentential switching because the speaker used Arabic in the first sentence, then he switched to Javanese in the second sentence. In this part of the drama conversation, Arabic became the main language used.

\section{Intra-Sentential Switching}

Tuman= Body shamming. Body niku awak, shamming niku isin. Body shamming ngisin-isini awak, Ndoro. 
Jadila: Journal of Development and Innovation

E-ISSN: 2723-6900

in Language and Literature Education

P-ISSN: 2745-9578

Publisher: Yayasan Karinosseff Muda Indonesia

Volume 1 Number 4, 2021

Page: $451-469$

The italic word classified as intra-sentential switching. The switching occurs within the sentence. The clause is in English and the following clause is in other language (Javanese).

\section{Types of Code-Mixing}

In analyzing forms of Code-Mixing, the researcher used the theory of Hoffman. The researcher found all types of Code-Mixing in drama conversation of ALE "Prahara Ing Argabelah". They are intra-sentential code mixing, intra-lexical code mixing, and involving a change of pronunciation. The finding of the research about Code-Mixing in drama conversation ALE "Prahara Ing Argabelah" as follows:

\section{Intra-Sentential Code Mixing}

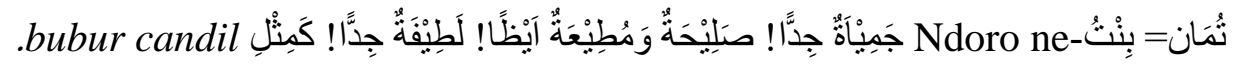

Based on the data above, it can be seen that in the end of Tuman's utterance, she inserted Indonesian words in her dominant language. Tuman said "bubur candil". This mixing includes in the intra-sentential code mixing because the mixing is in the form of phrase.

\section{Intra-Lexical Code Mixing}

Tumpang= Penonton! Balik lagi dichannel Youtube aku. Channel terkeren terkece terbadai terdahsyat terinbox ternyata si dia jalan sama mantannya. Dichannel Atta Harilibur.

This data is classified as intra-lexical code mixing. It can be seen that Tumpang gave the Indonesian affixation "ter" on the word "inbox". It is included Indonesian prefix. The structure is "ter as prefix and inbox as root", it becomes intralexical code mixing "terinbox". 
Jadila: Journal of Development and Innovation

E-ISSN: 2723-6900

in Language and Literature Education

P-ISSN: 2745-9578

Publisher: Yayasan Karinosseff Muda Indonesia

Volume 1 Number 4, 2021

Page: $451-469$

Tumpang= Ini ya gais, kita itu mau gerebek warga lokal Argabelah.

Liat ini! Ini botolnya banyak banget, ini bartendernya Argabelah gais. Namanya mbak siapa?

In this utterance, Tumpang used suffix in Indonesian "nya" and it was followed by English word "bartender", therefore the utterance was intra-lexical code mixing because in the utterance there is suffix in Indonesian and main word in English.

\section{Involving a Change of Pronunciation}

Tumpang= Mbok rewangi aku nggawe konten Yusup to!

The above utterance included in involving a change of pronunciation because she said "content" in Indonesian phonological structure.

\section{Functions of Code-Switching and Code-Mixing}

From seven functions of Code-Switching and Code-Mixing that proposed by Marasigan, the researcher found six functions from drama conversation in ALE "Prahara Ing Argbelah". They are addressee specification, repetition, interjection, message qualification, personalization and objectivization, and facility of expression.

\section{Addressee Specification}

Tumpang= Makane sinau sek tenanan! Nganu mbak, nganu teman-teman sekalian, download aplikasi jenenge unacademy.

Kui ki aplikasi pembelajaran. Didalamnya banyak mata kuliah sama simulasi ujian, bisa didapatkan secara gratis di Appstore maupun Playstore.

From the data above, the italic sentence performed Code-Switching as addressee specification. Tumpang switched her language when she wanted to send the message to Kinco and the viewer about unacademy application. 
Jadila: Journal of Development and Innovation

E-ISSN: 2723-6900

in Language and Literature Education

P-ISSN: 2745-9578

Publisher: Yayasan Karinosseff Muda Indonesia

Volume 1 Number 4, 2021

Page: $451-469$

Repetition

Narasoma $=$ What's so alike?

Pailul= Alike? Mirip?

From data above, "Mirip?" turned to repetition because it is used to repeat the meaning of the previous word. Pailul repeated her utterance in other language to emphasize the meaning so that the listener will not misunderstand about what Pailul meant.

\section{Interjection}

Pujawati $=\mathrm{He}$ is very handsome, gentle. He has thin moustache and also so macho, Bopo.

Bagaspati= Subhanallah. Who is he?

"Subhanallah" is an expression that used by Bagaspati to show his impression toward Pujawati's statement. Therefore, the expression classified as interjection.

\section{Message Qualification}

Tuman= Body shamming. Body niku awak, shamming niku isin. Body shamming ngisin-isini awak, Ndoro.

“...niku awak, ...niku isin, ...ngisin-ngisini awak” is categorized as message qualification. The speaker begin his utterance in English language then she change her language into Javanese to give qualification.

\section{Personalization and Objectivization}

Tuman= Perhaps you have feeling to him, Ndoro Ayu. Cie...cie...Ndoro Ayu jatuh cinta, ihirr...Ndoro Ayu jatuh cinta.

Tuman expresses her personal opinion toward Pujawati's feeling in other language. Therefore, it is categorized as personalization and objectivization. 
Jadila: Journal of Development and Innovation

E-ISSN: 2723-6900

in Language and Literature Education

P-ISSN: 2745-9578

Publisher: Yayasan Karinosseff Muda Indonesia

Volume 1 Number 4, 2021

Page: $451-469$

Facility of Expression

Narasoma $=$ Sorry, wait a second Resi.

What are you doing? You got scare like seeing a buto!

The italic word performed Code-Mixing as facility expression. Narasoma used the word "buto" to help him in producing a common word within the conversation. Therefore, the listener would understand easier toward his sentence.

\section{Conclusion}

The total data 24 unit of analysis of Code-Switching found that 6 data used tag-switching, 15 data used inter-sentential switching, and 3 data used intra-sentential switching. It showed that inter-sentential switching is commonly used in the drama conversation of ALE "Prahara Ing Argabelah". Moreover, 27 unit data analysis of Code-Mixing performed 21 data used intra-sentential code mixing, 5 data used intralexical code mixing, and 1 data used involving a change of pronunciation. Based on the data, the drama conversation in ALE "Prahara Ing Argabelah" commonly used intra-lexical code mixing.

From 24 unit of analysis of Code-switching, the researcher just found six functions in the drama conversation of ALE "Prahara Ing Argabelah". There are 6 addressee specifications, 2 repetitions, 6 interjections, 1 message qualification, 2 personalization and objectivizations, and 7 facility of expressions. Based on the data, the common function to be used is facility of expressions. Furthermore, the researcher just found 3 functions from 27 data analysis of Code-Mixing. There are 1 repetition, 2 message qualifications, and 24 facility of expressions. The function mostly used in the drama conversation of ALE "Prahara Ing Argabelah" is facility of expressions. 
Jadila: Journal of Development and Innovation

E-ISSN: 2723-6900

in Language and Literature Education

P-ISSN: 2745-9578

Publisher: Yayasan Karinosseff Muda Indonesia

Volume 1 Number 4, 2021

Page: $451-469$

\section{References}

Admaja, Y. W. (2013). The Research for Personal Identity in Oscar Wilde's The Importance of Being Earnest 1895: An Individual Psychological Perspective. Graduating Paper. Surakarta: Muhammadiyah University of Surakarta.

Ansar, F. A. (2017). Code Switching and Code Mixing in Teaching-Learning Process. Jurnal Tadris Bahasa Inggris. Vol. 10. No. 1.

Barman, Binoy. (2012). The Linguistic Philosophy of Noam Chomsky. Journal of Philosophy and Progress. Vol. L1-L11.

Denzin, N. K. (1978). The Research Act: A Theoretical Introduction to Sociological Methods Second Edition. New York: McGraw-Hill.

Heeti, N.H.A. and Addely A. (2016). Types and Functions of Code Switching in the English Language Used by Iraqi Doctors in Informal Settings. International Journal of Advanced Research and Review. Vol. 1. No. 8.

Herk, G. V. (2012). What is Sociolinguistics?. Oxford: Wiley Blackwell.

Hoffman, Ch. (1991). An Introduction to Bilingualism. New York: Routledge.

Holmes, J. (2013). An Introduction to Sociolinguistics Fourth Edition. London and New York: Routledge.

Marasigan, E. (1983). Code-Switching and Code-Mixing in Multilingual Societies: Monograph Series. Singapore: Singapore University Press.

Moloeng, L.J., Prof., M.M. (2009). Metode Penelitian Kualitatif Edisi Revisi. Bandung: Remaja Rosdakarya.

Poplack, S. (1980). Sometimes I'll start a sentence in English y termino on Espanol "Toward a typology of Code Switching. Linguistic 18. 581-616.

Risdianto, F. (2013). An Introduction to Sociolinguistics. Salatiga: STAIN Salatiga Press.

Saputro, A. (2013). The Analysis of Indonesian-English Code Mixing Used in Marmut Merah Jambu Novel. Unpublished Thesis. Salatiga: State Islamic College of Salatiga.

Sumarsih. (2014). Code Switching and Code Mixing in Indonesia: Study in Sociolinguistics. Jurnal English Language and Literature Studies. 4(1), 2.

Syafryadin, S., Rahmawati, I. N., \& Febriani, R. B. (2020). An analysis of code mixing used in opinion rubric of kompas newspaper. English Education: Jurnal Tadris Bahasa Inggris, 13(2), 173-193. 
Jadila: Journal of Development and Innovation

E-ISSN: 2723-6900

in Language and Literature Education

P-ISSN: 2745-9578

Publisher: Yayasan Karinosseff Muda Indonesia

Volume 1 Number 4, 2021

Page: 451-469

Syafryadin, S., \& Haryani, H. (2020). An analysis of English code mixing used in Indonesian magazine. Journal of Languages and Language Teaching, 8(4), 381-390.

Wardhaugh, R. (2006). An Introduction to Sociolingusitics Fifth Edition. UK: Blackwell Publishing. 